\title{
Determination of Chrysomelidae (Coleoptera) Species and Host Plants in Vegetable Areas of Burdur Province
}

\author{
Ebru Gül ASLAN iD 1*, Keriman VERGILI BILLKAY (D) 1 \\ ${ }^{1}$ Suleyman Demirel University, Faculty of Arts and Science, Biology Department, Isparta, Turkey \\ Geliş Tarihi (Received): 14.09.2021, Kabul Tarihi (Accepted): 21.10.2021 \\ $\square$ Sorumlu Yazar (Corresponding author*): ebruaslan@sdu.edu.tr \\ (C) +902462114053 通 +902462114399
}

\begin{abstract}
The study was carried out between the years 2019-2020 in order to determine the Chrysomelidae species and their host plants in the vegetable fields of greenhouses, gardens, and open fields located in the central district of Burdur province. As a result of 366 samples examined; 18 species belonging to 5 genera from Galerucinae subfamily, 2 species belonging to 2 genera from Chrysomelinae subfamily, and 1 species from Criocerinae subfamily were identified. Information about local distributions was added for each species. In addition, host plant relationships of the species that can be determined based on field observations, or previous literature information on host plants were given. Among the determined species Chaetocnema delarouzei (Brisout), Epitrix hirtipennis (Illiger), Epitrix pubescens (Koch), Longitarsus pellucidus (Foudras), Phyllotreta ochripes (Marsham), Gastrophysa polygoni (Linnaeus), Oulema melanopus (Linnaeus) and Leptinotarsa decemlineata (Say) were recorded for the first time from Burdur province with this study.
\end{abstract}

Keywords: Burdur, Chrysomelidae, Coleoptera, fauna, host plant, vegetable areas

\section{Burdur İli Sebze Alanlarının Chrysomelidae (Coleoptera) Türleri ve Konak Bitkilerinin Belirlenmesi}

ÖZ

Çalışma, 2019-2020 yılları arasında Burdur ili merkez ilçedeki seralar, bahçeler ve açık tarlalarda bulunan sebze alanlarındaki Chrysomelidae familyasına ait türlerin ve konak bitkilerinin belirlenmesi amacıyla yapılmıştır. Toplamda 366 örnek incelenmiş ve sonuçta; Galerucinae altfamilyasından 5 cinse ait 18 tür, Chrysomelinae altfamilyasından 2 cinse ait 2 tür ve Criocerinae altfamilyasından 1 tür tespit edilmiştir. Türlerin her birinin lokal dağılış bilgileri verilmiştir. Ayrıca arazi gözlemlerine dayalı olarak türlerin belirlenebilen konak bitki ilişkileri veya önceki konaklarına dair literatür bilgileri eklenmiştir. Belirlenen türler arasında Chaetocnema delarouzei (Brisout), Epitrix hirtipennis (Illiger), Epitrix pubescens (Koch), Longitarsus pellucidus (Foudras), Phyllotreta ochripes (Marsham), Gastrophysa polygoni (Linnaeus), Oulema melanopus (Linnaeus) ve Leptinotarsa decemlineata (Say) Burdur'dan ilk kez bu çalışmayla kaydedilmiştir.

Anahtar Kelimeler: Burdur, Chrysomelidae, Coleoptera, fauna, konak bitki, sebze alanları

\section{INTRODUCTION}

Chrysomelidae represents one of the most numerous and most studied families of Coleoptera. The actual number of described species reaches about 40.000 throughout the world (Santiago-Blay, 2004; Biondi et al., 2013), while the estimated number probably ranges from 55.000 to 60.000 species (Jolivet, 2015). 
The Palaearctic fauna comprises more than 3.500 species (Konstantinov et al., 2009), and the Turkish Chrysomelidae fauna (excluding Bruchinae) includes over 900 taxa (Ekiz et al., 2013; Özdikmen et al., 2014; Aslan and Başar, 2016).

Chrysomelidae, or leaf beetles, are phytophagous insects adapted to feed on a wide range of plant groups. Both the adult and larvae feed on cultivated plants as well as some useful wild plants or shrubs (Jolivet et al., 1988). The close association between the group and plants is important both ecologically and economically due to their impact on agriculture. Many species are harmful and known as serious pests of food crops, tree and shrub plantations, medical herbs and fodder crops, although several are beneficial as biological control agents of weeds (Booth et al., 1990; Jolivet and Verma, 2002). Species belonging to the tribe Alticini (especially species from Phyllotreta and Epitrix) come first among the leaf beetles that damage vegetables (Aslan and Özbek, 1998; 2000; Aslan et al., 2003). They may cause significant crop loss when many species reach high populations in cultivated areas.

The aim of this study is to contribute the knowledge of Chrysomelidae species that occur in vegetable areas of Burdur province with their host plant information.

\section{MATERIAL AND METHODS}

The present study is based upon leaf beetle samples collected from the vegetables in greenhouses, gardens and open fields located in the central district of Burdur province (Figure 1). Field studies were carried out at regular intervals during the months of September-November 2019 and March-July 2020.

Specimens were collected by using sweep net and mouth aspirator, or by hand if necessary. Plants with leaves showing feeding marks were also carefully examined and searched for beetles. Plant species on which beetles were seen feeding constantly in the field observations were considered to be potential host plants. Collected beetles were taken to the laboratory to be mounted and labeled. Specimens were identified to species under an Olympus SZ61 stereomicroscope according to the taxonomic keys and figures given by Döberl (2000), Čižek and Doguet (2008), Warchałowski (2010) and Konstantinov et al. (2011).

Voucher specimens are deposited at the Systematic Entomology Laboratory in Biology Department of Süleyman Demirel University, Isparta, Turkey.

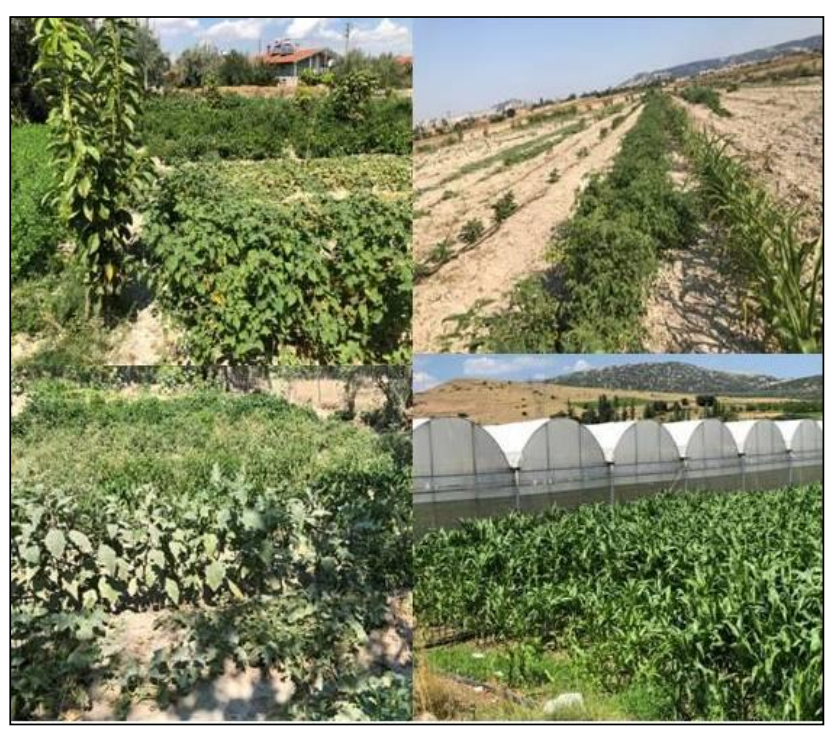

Figure 1. Photos from the surveyed fields

\section{RESULTS}

As a result of field studies conducted in vegetable areas of Burdur (central district) province, 366 leaf beetle samples belonging to 21 species were determined. The list of species is given below. Turkish distributions by province are given for each species with some notes about host plants.

\section{Family Chrysomelidae Latreille, 1802 Subfamily Galerucinae Latreille, 1802 Tribe Alticini Spinola, 1844}

\section{Genus Chaetocnema Stephens, 1831}

\section{Chaetocnema breviuscula (Faldermann, 1837)}

Material examined: Bahçelievler, Körpınar,

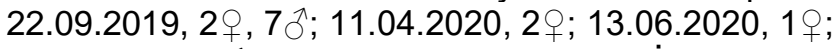
11.07.2020, 1 ; 22.08.2020, 1o; Bağlar, İnce saylar, 28.09.2019, 10; 12.04.2020, 2o; Bahçelievler, Ilıca ayağı, 03.10.2019, 10; 14.03.2020, 10, 1ో; Bağlar, Topraklık, 29.03.2020, 1q, 1ో;; Kışla, Köyiçi,

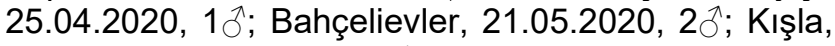
Köyderesi, 27.06.2020, $1 \delta^{\Uparrow}$; Kurna, Karen, 08.08.2020,

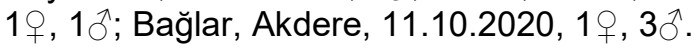

Distribution in Turkey: Adana, Aksaray, Ankara, Burdur, Erzurum, Eskişehir, İstanbul (Anatolian part), Mersin, Sakarya, Samsun, Sivas, Tokat (Ekiz et al., 2013; Özdikmen, 2014; Aslan et al., 2015).

Host plant information: The previous host plants for this species were reported as Chenopodiaceae (Čížek 
and Doguet, 2008), Beta vulgaris, Salsola kali and Atriplex halimus (Konstantinov et al., 2011). It was collected from the vegetables by sweeping, the exact host plant is not known.

\section{Chaetocnema delarouzei (Brisout, 1884)}

Material examined: Bağlar, İnce Saylar, 23.08.2020,

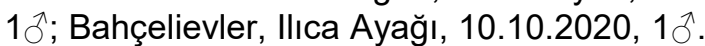

Distribution in Turkey: Isparta (Gök and Aslan, 2005). Present study represents the first record for Burdur province.

Host plant information: It was collected from the vegetables by sweeping, so the host plant could not be determined. No host plant records were found in the literature.

\section{Chaetocnema scheffleri (Kutschera, 1864)}

Material examined: Bahçelievler, Körpınar,

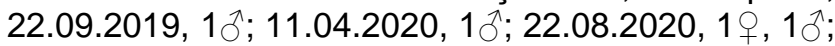
Bahçelievler, Kokarpınar, 28.03.2020, 20; Bahçelievler, Yazıbaşı, 09.05.2020, 1 ; Karasenir, Karaburun, 10.05.2020, 2ᄋ; Bahçelievler, 21.05.2020, 1§; Bahçelievler, Ilıca Ayağı, 10.10.2020, 1 \%, $1 \delta^{\Uparrow}$.

Distribution in Turkey: Antalya, Ankara, Burdur, Erzurum, Isparta, İstanbul, İzmir, Konya (Ekiz et al., 2013; Özdikmen, 2014; Aslan et al., 2015).

Host plant information: Rumex, Rumex pulcher, $R$. acetosella, $R$. angiocarpus, Polygonum patulum, Fagopyrum esculentum were listed among the previous host plants of this species (Konstantinov et al., 2011). The exact host plant could not be determined in this study.

\section{Chaetocnema tibialis (IIliger, 1807)}

Material examined: Bahçelievler, Körpınar, 22.09.2019, 1क; 13.06.2020, 1q, 20; 11.07.2020, 1क; 22.08.2020, 10; Bağlar, İnce Saylar, 12.04.2020, 1 \%; Kışla, Köyiçi, 25.04.2020, 2ᄋ; Karasenir, Karaburun, 10.05.2020, 2क, 1\}; 27.09.2020, 2o; Bahçelievler, llıca Ayağı, 20.05.2020, 2o, 1ో;; Bahçelievler, 21.05.2020, 1; Kışla, Köyderesi, 27.06.2020, 2 \% ; 13.09.2020, 3ㅇ, 1§ో; Bahçelievler, Yazıbaşı, 25.07.2020, 1\%; Bahçelievler, Kokarpınar, 26.09.2020, 1ㅇ; Bağlar, Akdere, 11.10.2020, 1 ㅇ.

Distribution in Turkey: Aksaray, Amasya, Ankara, Antalya, Balıkesir, Burdur, Çanakkale, Düzce, Erzincan, Erzurum, Eskişehir, Isparta, İzmir, Kars, Kocaeli, Konya, Malatya, Samsun (Ekiz et al., 2013; Özdikmen, 2014; Aslan et al., 2015).

Host plant information: The species has a wide distribution, and causes low yield in production due to the damage it causes to sugar beet (Rashidov and
Khasanov, 2003; Yaman et al., 2008). There are other host plant records for this species from Atriplex, Amaranthus, Chenopodium, Sinapis, Salicornia, Rumex, Portulaca, Ipomea, Spinacia, Beta and Polygonum (Aslan et al., 2003; Çam and Atay, 2004; Konstantinov et al., 2011). The species was sampled from the sugar beet and purslane in the study area.

\section{Genus Epitrix Foudras, 1860}

\section{Epitrix hirtipennis (Melsheimer, 1847)}

Material examined: Bahçelievler, Körpınar,

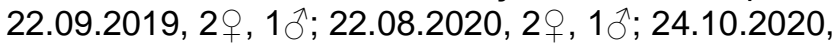

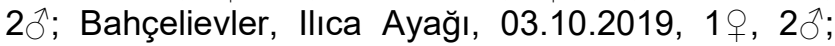
Bahçelievler, Kokarpınar, 13.10.2019, 2\%, 10;

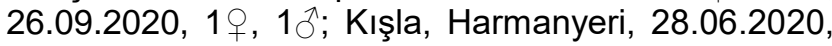

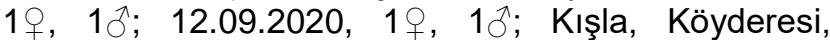
13.09.2020, 3우, 1§; Bağlar, Ünce Saylar, 25.10.2020, 2 ㅇ.

Distribution in Turkey: Ankara, İzmir, Mardin, Zonguldak (Ekiz et al., 2013; Özdikmen et al., 2017). Present study represents the first record for Burdur province.

Host plant information: E. hirtipennis is typically a tobacco pest. It is usually known as pest of tobacco, potato, tomato and eggplant throughout the world. It is also observed on peas, cabbage, pepper and radish (Capinera, 2001). Its host plant was determined as eggplant in the study area.

\section{Epitrix pubescens (Koch, 1803)}

Material examined: Bahçelievler, Körpınar, 11.04.2020, 1ㅇ, 1 ${ }^{\Uparrow}$; 13.06.2020, 1 ; Karasenir, Karaburun, 10.05.2020, 1§; Bahçelievler, Ilıca Ayağı,

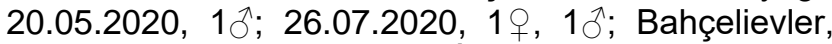
21.05.2020, 1, 1ㅊ; Bağlar, İnce Saylar, 14.06.2020,

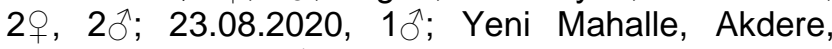
09.08.2020, 1 ㅇ, 1 त.

Distribution in Turkey: Ankara, Balıkesir, Bartın, Bilecik, Çankırı, Denizli, Düzce, Erzurum, Eskişehir, İstanbul, Kırklareli, Ordu, Tokat, Zonguldak (Çam and Atay, 2008; Ekiz et al., 2013; Özdikmen et al., 2017). The species was recorded for the first time from Burdur province.

Host plant information: Its host plants were previously reported as radish (Raphanus sativus), maize (Zea mays), beans (Phaseolus vulgaris), cabbage (Brassica oleracea) and potato (Solanum tuberosum) (Özdikmen et al., 2017). It was collected by sweeping from the vegetables in the fields. The exact host plant could not be determined. 


\section{Genus Longitarsus Berthold, 1827}

\section{Longitarsus pellucidus (Foudras, 1860)}

Material examined: Karasenir, Karaburun, 27.09.2020, 1 ㅇ.

Distribution in Turkey: Adana, Amasya, Ankara, Antalya, Artvin, Bayburt, Erzincan, Erzurum, Gümüşhane, Iğdır, Isparta, İzmir, Kars, Sivas, Tokat (Ekiz et al., 2013). The species was recorded for the first time from Burdur province.

Host plant information: It was collected by sweeping from vegetables. Convolvulus arvensis L., known as the host plant of this species, is frequently seen in vegetable areas and fruit gardens (Aslan and Gök, 2006; Č́žek and Doguet, 2008). It is highly probable that the species came from this plant while sweeping.

\section{Genus Phyllotreta Chevrolat, 1837}

\section{Phyllotreta atra (Fabricus, 1775)}

Material examined: Bağlar, İnce Saylar, 28.09.2019,

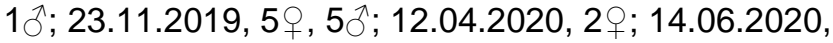

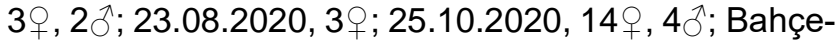
lievler, Kokarpınar, 13.10.2019, 2q, 1\}; 12.07.2020, 5ㅇ, 3ㅊ; Bahçelievler, Yazıbaşı, 09.11.2019, 3 25.07.2020, 2o, 23; Bahçelievler, llıca Ayağı, 14.03.2020, 20̂; Bağlar, Topraklık, 29.03.2020, 4ㅇ,

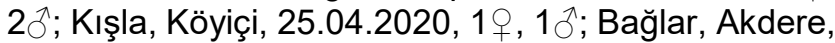
26.04.2020, 5, 1 ; $^{2}$ 11.10.2020, 1 ; Karasenir, Karaburun, 10.05.2020, 3q, 1 \%; Bahçelievler, 21.05.2020,

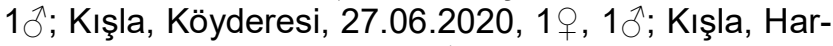
manyeri, 28.06.2020, 3, 1 ; Bahçelievler, Körpınar,

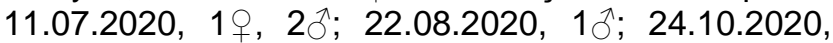
15우, 3ㅊ; Bahçelievler, Ilıca, 26.07.2020, 3 웅 Yeni Mahalle, Akdere, 09.08.2020, 2 \%.

Distribution in Turkey: Ankara, Antalya, Bayburt, Bolu, Burdur, Edirne, Eskişehir, Erzurum, Gümüşhane, Isparta, Kayseri, Kocaeli, Niğde, Rize, Samsun, Sivas, Trabzon (Ekiz et al., 2013; Aslan et al., 2015).

Host plant information: It causes damage to various plants from Brassicaceae, Resedaceae, and Capparidaceae (Capinera, 2008; Čížek and Doguet, 2008). Samples were collected from the vegetables by sweeping, and the exact host plant could not be determined.

\section{Phyllotreta corrugata Reiche \& Saulcy, 1858}

Material examined: Bahçelievler, Yazıbaşı, 09.05.2020, 1 \%.
Distribution in Turkey: Adana, Afyon, Ankara, Antalya, Burdur, Hatay, Isparta, İzmir, Kayseri, Konya, Sivas, Tokat, Yozgat (Ekiz et al., 2013; Aslan et al., 2015).

Host plant information: The specimen was collected by sweeping from the vegetable areas, and the host plant could not be determined.

\section{Phyllotreta cruciferae (Goeze, 1777)}

Material examined: Bahçelievler, Yazıbaşı,

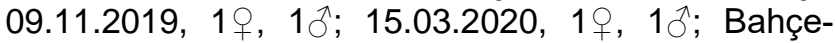

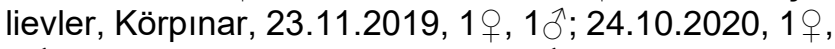
6 ; Bağlar, Akdere, 26.04.2020, 20; Karasenir, Karaburun, 10.05.2020, 1q, 1ठ; Bağlar, İnce Saylar, 25.10.2020, 5 今े.

Distribution in Turkey: Adana, Amasya, Ankara, Bilecik, Bursa, Burdur, Çankırı, Çorum, Edirne Eskişehir, Erzurum, Isparta, İzmir, Kayseri, Konya, Manisa, Niğde, Tokat, Trabzon (Ekiz et al., 2013).

Host plant information: It is an oligophag species generally feeding on Brassicaceae including Sinapis spp., Rorippa spp., Arabis spp., Alyssum spp., Sisymbrium spp., Brassica napus, Brassica oleracea and Cardamine amara (Čižek and Doguet, 2008), but also has been reported on Ficaria verna from Ranunculaceae (Gavrilović and Ćurčić, 2013). It is also one of the most serious pests of Brassica rapa and $B$. napus (canola) which are important cultivated plants used in industrial products (Gavloski et al., 2000). It was collected from cabbage in the present study.

\section{Phyllotreta erysimi Weise, 1900}

Material examined: Bağlar, İnce Saylar, 28.09.2019, 1; Bahçelievler, Körpınar, 22.09.2019, 2\%; 11.07.2020, 3q; 22.08.2020, 2 + , 1 đ; Bahçelievler, Kokarpınar, 13.10.2019, 2o; Bahçelievler, Yazıbaşı,

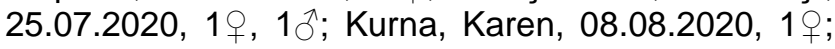
Bahçelievler, Ilıca Ayağı, 10.10.2020, 1 . .

Distribution in Turkey: Ankara, Antalya, Bayburt, Burdur, Erzurum, Isparta, Konya, Manisa, Samsun, Trabzon (Ekiz et al., 2013; Aslan et al., 2015).

Host plant information: The specimens were collected from sunflower and maize plants occurring in the study areas.

\section{Phyllotreta fornuseki (Č́ǐzek, 2003)}

Material examined: Bağlar, İnce Saylar, 28.09.2019,

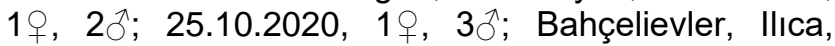
26.07.2020, 19, 2今; Yeni Mahalle, Akdere, 09.08.2020, 1 , $2{ }^{\uparrow}$.

Distribution in Turkey: Isparta, Burdur (Ekiz et al., 2013; Aslan et al., 2015). 
Host plant information: Sisymbrium spp. from Brassicaceae was reported as its host plant previously (Čižek and Doguet, 2008). The host plant could not be determined in this study.

\section{Phyllotreta nigripes (Fabricius, 1775)}

Material examined: Bahçelievler, Körpınar, 11.07.2020, 2q, 3 ${ }^{\wedge}$; 22.08.2020, 1; Bahçelievler, Yazıbaşı, 25.07.2020, 1, 10; Kurna, Karen, 08.08.2020, 1 गे.

Distribution in Turkey: Adana, Ankara, Antalya, Burdur, Bayburt, Bilecik, Edirne, Erzincan, Eskişehir, Erzurum, Hatay, Iğdır, Isparta, Kayseri, Konya, Kars, Manisa, Mersin, Sivas, Yozgat (Ekiz et al., 2013; Aslan et al., 2015).

Host plant information: Plants from Brassicaceae and Resedaceae were listed as host records for this species (Čížek and Doguet, 2008). In the present study, specimens were sampled from maize.

\section{Phyllotreta ochripes (Curtis, 1837)}

Material examined: Bahçelievler, Körpınar, 22.09.2019, 1q; 22.08.2020, 1ㅇ; Bahçelievler, Ilıca Ayağı, 20.05.2020, 2 .

Distribution in Turkey: Giresun, Istanbul (Anatolian part), Niğde (Ekiz et al., 2013). The species was recorded for the first time from Burdur province.

Host plant information: Host plant could not be determined.

\section{Phyllotreta punctulata (Marsham, 1802)}

Material examined: Bahçelievler, Kokarpınar, 12.07.2020, 2đ; Kurna, Karen, 08.08.2020, 1 औ.

Distribution in Turkey: Antalya, Bursa, Burdur, Eskişehir, Giresun, Isparta, Istanbul (Anatolian part), Kırklareli (Ekiz et al., 2013).

Host plant information: Previous host records for this species were given as Brassica spp., Sinapis spp., Sisymbrium spp., Alliaria spp., and Erysimum spp. (Čížek and Doguet, 2008). Its host plant could not be determined in this study.

\section{Phyllotreta variipennis (Boieldieu, 1859)}

Material examined: Bahçelievler, Körpınar, 22.09.2019, 2\}; 11.07.2020, 2o, 3 ; 22.08.2020, 2ᄋ, 2犬; 24.10.2020, 1, 1今; Bağlar, İnce Saylar,

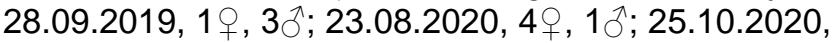
1今; Karasenir, Karaburun, 10.05.2020, 1, 2\}; Bahçelievler, Yazıbaşı, 25.07.2020, 1, 20; Kurna, Karen, 08.08.2020, 1ㅇ, 2§; Yeni Mahalle, Akdere, 09.08.2020, 2o; Kışla, Harmanyeri, 12.09.2020, 1 q ,

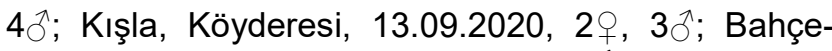
lievler, Kokarpınar, 26.09.2020, 2ㅇ, 3 ; Bahçelievler, llıca Ayağı, 10.10.2020, 1 స.

Distribution in Turkey: Ankara, Burdur, Eskişehir, Isparta, Istanbul (Anatolian part) Izmir (Ekiz et al., 2013; Aslan et al., 2015).

Host plant information: It was collected from cabbage. It has been observed that the specimens cause serious damage to the leaves while feeding.

\section{Phyllotreta vittula (Redtenbacher, 1849)}

Material examined: Bağlar, Akdere, 11.10.2020, $1 \hat{\jmath}$. Distribution in Turkey: Ankara, Antalya, Burdur, Edirne, Erzurum, Isparta, Izmir (Ekiz et al., 2013; Aslan et al., 2015).

Host plant information: It is known as a pest of cabbage, radish, turnip and rapeseed (Aslan and Özbek, 2000). There are host records on plants belonging to the families Brassicaceae, Poaceae and Asteraceae (Čížek and Doguet, 2008). Host plant could not be determined.

\section{Genus Psylliodes Berthold, 1827}

\section{Psylliodes tricolor Weise, 1888}

Material examined: Bahçelievler, llıca Ayağı, 03.10.2019, 1 , 1 1 1 .

Distribution in Turkey: Aksaray, Ankara, Antalya, Artvin, Bayburt, Burdur, Çankırı, Diyarbakır, Elazığ, Erzincan, Erzurum, Eskişehir, Hatay, Isparta, Kayseri, Kırşehir, Konya, Nevşehir, Niğde, Osmaniye, Samsun (Ekiz et al., 2013; Bal et al., 2018a; Aslan et al., 2020). Host plant information: It was collected by sweeping from vegetables. Host plant could not be determined.

\section{Subfamily Chrysomelinae Latreille, 1802}

Genus Gastrophysa Chevrolat, 1837

\section{Gastrophysa polygoni (Linnaeus, 1758)}

Material examined: Bahçelievler, Körpınar, 11.04.2020, 1ㅇ, 2خ; 11.07.2020, 1, $2 \hat{O}$.

Distribution in Turkey: Adana, Aksaray, Amasya, Ankara, Ardahan, Artvin, Bolu, Çankırı, Denizli, Diyarbakır, Düzce, Edirne, Erzincan, Eskişehir, Erzurum, Isparta, İstanbul, İzmir, Kahramanmaraş, Karaman, Karabük, Kars, Kastamonu, Kayseri, Konya, Mersin, Nevşehir, Niğde, Ordu, Samsun, Sinop, Trabzon, Tokat, Yozgat (Ekiz et al., 2013). The species was recorded for the first time from Burdur province. 
Host plant information: According to Çam and Atay (2006) specimens of this species feed intensely on $P O-$ lygonum aviculare, $P$. cognatum, $P$. convolvulus, $R u$ mex spp. (Polygonaceae), Chenopodium album and Beta vulgaris (Chenopodiaceae). It was collected from poppy and cress in the present study.

\section{Genus Leptinotarsa Chevrolat, 1837}

\section{Leptinotarsa decemlineata (Say, 1824)}

Material examined: Bağlar, Akdere, 31.10.2019, 1q,

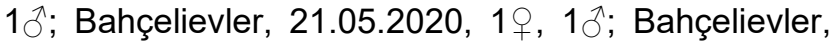

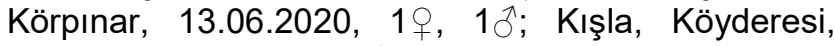
27.06.2020, 1ㅇ, 1ㅊ; Bahçelievler, Yazıbaşı, 25.07.2020, 1 우, 1 万人.

Distribution in Turkey: Adana, Afyon, Aksaray, Ankara, Artvin, Bolu, Çanakkale, Çankırı, Düzce, Edirne, Erzincan, Eskişehir, Erzurum, Kahramanmaraş, Karaman, Kastamonu, Kayseri, Nevşehir, Niğde, Osmaniye, Sinop, Tekirdağ, Tokat, Zonguldak (Ekiz et al., 2013; Bal et al., 2018b). Present study represents its first record from Burdur province.

Host plant information: The main host plants of potato beetle in Turkey are potato and eggplant. Tomatoes and some wild Solanaceae species are also listed among its hosts (Erdoğan, 2006). Samples of this species were collected from tomato and potato plants in this study. It has been observed that adults and larvae fed heavily especially on potato leaves and caused serious damage.

\section{Subfamily Criocerinae (Latreille, 1804)}

\section{Genus Oulema Gozis, 1886}

\section{Oulema melanopus (Linnaeus, 1758)}

Material examined: Bahçelievler, Körpınar, 11.04.2020, 1, $2{ }^{\wedge}$.

Distribution in Turkey: Adana, Afyon, Aksaray, Ankara, Antalya, Ardahan, Aydın, Çanakkale, Çorum, Diyarbakır, Edirne, Erzincan, Erzurum, Eskişehir, Gaziantep, Hatay, Iğdır, İzmir, Kahramanmaraş, Karabük, Karaman, Kars, Kastamonu, Kırıkkale, Kırklareli, Kütahya, Konya, Manisa, Mersin, Muğla, Osmaniye, Samsun, Siirt, Tekirdağ (Özdikmen et al., 2012; Ekiz et al; 2013; Özdikmen and Özbek, 2014). The species was recorded for the first time from Burdur province.

Host plant information: Oulema melanapus, known as the cereal leaf beetle, is an invasive crop pest; especially on wheat and small grains (Olfert et al., 2004). The specimens were collected from poppy and cress plants in the study area.

\section{DISCUSSION AND CONCLUSIONS}

The present study was carried out in order to determine the Chrysomelidae species and their host plants occurring in vegetable areas of greenhouses, gardens and open fields in the central district of Burdur province. As a result; 18 species belonging to 5 genera from Galerucinae, 2 species belonging to 2 genera from Chrysomelinae, and 1 species from Criocerinae were determined. Distributions of the total 21 species according to the genera are Phyllotreta 10, Chaetocnema 4, Epitrix 2, Longitarsus 1, Psylliodes 1, Gastrophysa 1, Oulema 1 and Leptinotarsa 1, respectively. Eight of them are firstly recorded from Burdur province including Chaetocnema delarouzei, Epitrix hirtipennis, E. pubescens, Longitarsus pellucidus, Phyllotreta ochripes, Gastrophysa polygoni, Oulema melanopus and Leptinotarsa decemlineata.

Among the leaf beetles gathered fom vegetable areas, Phyllotreta was the most frequently sampled genus in terms of both species number and the density of individuals. Phyllotreta species are known as major insect pests of several crops and various common weeds (Lundin, 2020). The feeding preference of these beetles mostly includes the family Brassicaceae or the related genera from Amaranthaceae, Capparidaceae, Chenopodiaceae and Resedaceae (Furth, 1979; Nielsen, 1988; Aslan and Gök, 2006; Čížek and Doguet, 2008). Therefore, specimens of this genus were collected from almost all vegetables in large or little numbers during the field studies. However, it was observed that they were densely occur on radish, maize and cabbage, and they damaged radish and cabbage leaves by producing small, tiny holes (Figure 2).

Phyllotreta atra, P. corrugata, P. cruciferae, $P$. fornuseki and $P$. punctulata are similar to each other in terms of morphological features and it is difficult to distinguish them in field conditions. So, it could not be clearly determined which species actually damage on radish leaves. It was observed that Phyllotreta variipennis and $P$. cruciferae caused significant damage to cabbage. Additionally, Phyllotreta erysimi was collected from maize and sunflower leaves, and $P$. nigripes was sampled from maize leaves. 

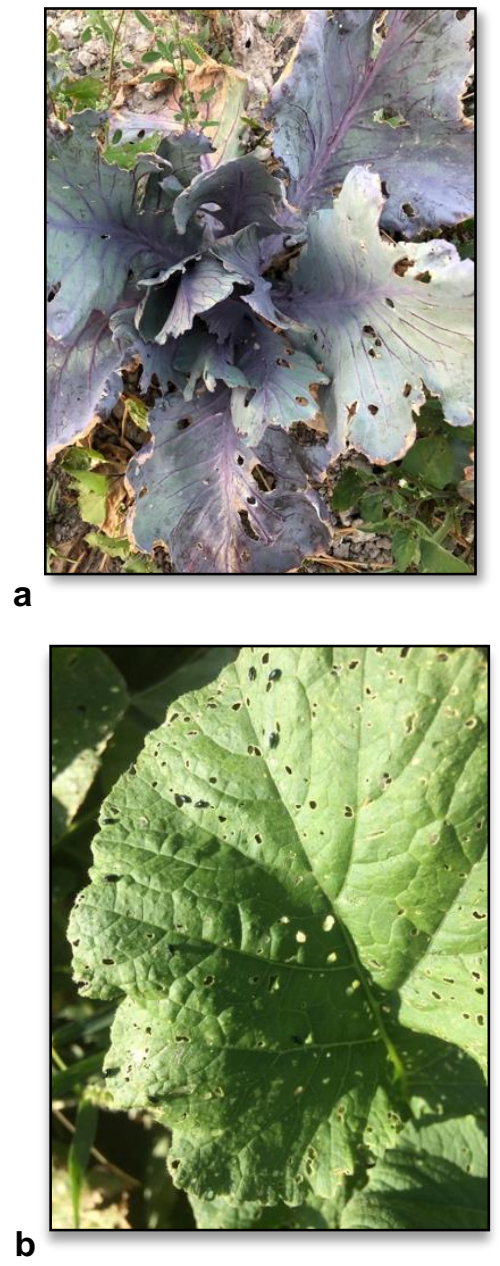

Figure 2. a. Damage of Phyllotreta variipennis on cabbage b. Phyllotreta spp. on radish leaf

Chaetocnema and Epitrix were the other common genera in the surveyed fields after Phyllotreta. Species belonging to Chaetocnema were mostly collected from sugar beet and purslane. It has been observed that they cause damage by opening holes in the leaves, especially on sugar beet. It is known that Epitrix species prefer to feed on solanaceous plants. Epitrix hirtipennis was sampled more frequently starting with the end of August, and its host plant was determined as eggplant (Solanum melongena L.) in the study area.

Specimens of Leptinotarsa decemlineata, a major pest of potato worldwide, were collected from potato and tomato leaves in the research area. It has been determined that the pest causes product losses up to 70$80 \%$ in potatoes (Oerke et al., 1994). Although the most suitable host of the potato beetle is potato, when it cannot find this plant, it also feeds on tomato, eggplant, tobacco and pepper plants belonging to the family Solanaceae (Kekillioğlu and Yılmaz, 2018).

The rarest species of the study area were Longitarsus pellucidus, Psylliodes tricolor, and Oulema melanopus. The mentioned species were collected with one, two or three samples. It is thought that these species are associated with the plant diversity in the close vicinity of the study areas, and were sampled randomly during the transition between plants.

Consequently; every year, new Chrysomelidae species are described for the scientific world from Turkey, new host plant relationships of the group are determined, new pests or biological control agents are found. The Chrysomelidae is therefore a group with many interesting species to study, and more to discover. Considering that our country has regions that have never been studied in terms of Chrysomelidae fauna, it is a fact that the number of known species can be increased much higher. Studies on host plant relations of the group are as valuable as faunistic studies. The strong evolutionary link between plants and leaf beetles increases the importance of the group in agricultural terms.

\section{ACKNOWLEDGEMENTS}

This study is a part of the second author's master thesis and was supported by the Department of Scientific Research Project Management of Süleyman Demirel University (SDUBAP), with the project number FYL2019-7380.

\section{REFERENCES}

Aslan, I., Özbek, H. (1998). Erzurum'da sebzelerde zarar yapan yaprak böcekleri (Coleoptera, Chrysomelidae). 2. Sebze Tarımı Sempozyumu, 28-30 Eylül, Tokat, 335340.

Aslan, İ., Özbek, H. (2000). Phyllotreta (Coleoptera, Chrysomelidae, Alticinae) species, their biology and damage in some vegetables in Cruciferae family. Proceedings of the Third Vegetable Symposium, 11-13 September, Isparta, 203-207.

Aslan, İ., Özbek, H., Konstantinov, A. (2003). Flea beetles (Coleoptera: Chrysomelidae) occurring on Amaranthus retroflexus L. in Erzurum province, Turkey, and their potential as biological control agents. Proceedings of the Entomological Society of Washington, 105(2): 441446.

Aslan, E.G., Gök, A. (2006). Host-plant relationships of 65 flea beetles species from Turkey, with new associations (Coleoptera: Chrysomelidae: Alticinae). Entomological News, 117(3): 297-308. 
Aslan, B., Yılmaz, A., Bayram, F., Aslan, E.G. (2015). Contributions to the insect fauna of Burdur Province (Turkey) in terms of Hydrophilidae, Helophoridae and Chrysomelidae (Coleoptera) with Chorotype Analyses. Fresenius Environmental Bulletin, 24(5b): 1932-1939.

Aslan, E.G, Kaya, Ö.D., Ünal, E. (2020). Contributions to the knowledge of leaf beetle (Coleoptera: Chrysomelidae) fauna in Elazığ, Erzincan and Tunceli provinces, Turkey. The Journal of Graduate School of Natural and Applied Sciences of Mehmet Akif Ersoy University, 11(Suppl. 1): 273-280.

Aslan, E.G., Başar, M. (2016). Flea beetles collected from olive trees of Antalya province including the first record of the monotypic genus Lythraria Bedel, 1897 (Coleoptera: Chrysomelidae) for Turkey. Turkish Journal of Entomology, 40(3): 243-248.

Bal, N., Özdikmen, H., Coral Şahin, D. (2018a). Twenty-six new flea beetles for the fauna of Çankırı province in Turkey (Chrysomelidae: Galerucinae: Alticini). Munis Entomology and Zoology, 13(2): 527-537.

Bal, N., Özdikmen, H., Kıyak, S. (2018b). Thirty new leaf beetles for the fauna of Çankırı province in Turkey (Chrysomelidae). Munis Entomology and Zoology, 13(2): 507-518.

Biondi M., Urbani, F., D'Alessandro, P. (2013). Endemism patterns in the Italian leaf beetle fauna (Coleoptera: Chrysomelidae). ZooKeys, 332: 177-205.

Booth, R.G., Cox, M.L., Madge, R.B. (1990). Guides to insects of importance to man 3. Coleoptera. University Press, Cambridge, United Kingdom.

Capinera, J.L. (2001). Handbook of vegetable pests. Academic Press, San Diego.

Capinera, J.L. (2008). Encyclopedia of Entomology. $2^{\text {nd }}$ edition. Vols. 1-4 Springer, Dordrecht, The Netherlands.

Čížek, P., Doguet, S. (2008). Klic k urcovani drepciku (Coleoptera: Chrysomelidae: Alticinae) Ceska a Slovenska. Mestske muzeum, Nove Mesto nad Metuji, Slovenska.

Çam, H., Atay, T. (2004). Tokat ilinde bazı yabancı otlar üzerinde beslenen yaprak böcekleri (Coleoptera, Chrysomelidae). GOÜ Ziraat Fakültesi Dergisi, 21(2): 7-14.

Çam, H., Atay, T. (2006). Tokat ili Chrysomelinae ve Cryptocephalinae (Coleoptera: Chrysomelidae) türleri üzerinde faunistik araştırmalar. Türkiye Entomoloji Dergisi, 30(4): 285-302.

Çam, H., Atay, T. (2008). The faunistic studies on the subfamily Alticinae (Coleoptera: Chrysomelidae) species in Tokat province. International Journal of Natural and Engineering Sciences, 2(3): 21-26.

Döberl, M. (2000). Beitrag zur Kenntnis der Gattung Epitrix Foudras, 1860 in der Paläarktis. Mitteilungen des Internationalen Entomologischen Vereins, 25 (1/2): 1-23.

Ekiz, A.N., Şen, İ., Aslan, E.G., Gök, A. (2013). Checklist of leaf beetles (Coleoptera: Chrysomelidae) of Turkey, excluding Bruchinae. Journal of Natural History, 47: 22132287.

Erdoğan, P. (2006). Sebze ve yem bitkilerinde görülen zararlılar ve mücadele yöntemleri. Tarla Bitkileri Merkez Araştırma Enstitüsü Dergisi, 15(1): 1-10.
Furth, D.G. (1979). Zoogeography and host plant ecology of the Alticinae of Israel, especially Phyllotreta; with descriptions of three new species (Coleoptera: Chrysomelidae). Israel Journal of Zoology 28(1): 1-37.

Gavloski, J.E., Ekuere, U., Keddie, A., Dosdall, L., Kott, L., Good, A.G. (2000). Identification and evaluation of flea beetle (Phyllotreta cruciferae) resistance within Brassicaceae. Canadian Journal of Plant Science, 80(4): 881 887.

Gavrilović, B., Ćurčić, S. (2013). The diversity of the family Chrysomelidae (Insecta: Coleoptera) of the Obedska Bara Special Nature Reserve (Vojvodina Province, Serbia), with special reference to the host plants. Acta Zoologica Bulgarica, 65(1): 37- 44.

Gök, A., Aslan (Çilbiroğlu), E.G. (2005). Two flea beetles (Coleoptera: Chrysomelidae) new for fauna of Turkey. Journal of the Entomological Research Society, 7(1): 59-61.

Jolivet, P., Pepitpierre, E., Hsiao, T. H. (1988). Biology of Chrysomelidae. Series Entomologia, Kluver Academic Publishers.

Jolivet, P., Verma, K.K. (2002). Biology of Leaf Beetles. Intercept Publisher, Andover, United Kingdom.

Jolivet, P. (2015). Together with 30 years of symposia on Chrysomelidae! Memories and personal reflections on what we know more about leaf beetles. ZooKeys, 547: 35-61.

Kekillioğlu, A., Yılmaz, M. (2018). Patates böceği [Leptinotarsa decemlineata Say. (Coleoptera: Chrysomelidae)]'nin Nevşehir ilinde yaşamsal etkileşim ve çeşitliliği üzerine bir ön çalışma. ANADOLU, Journal of $A e-$ gean Agricultural Research Institute, 28(1): 100-107.

Konstantinov, A.S., Korotyaev, B.A., Volkovitsh, M.G. (2009). Insect biodiversity in the Palearctic Region. In: Insect Biodiversity: Science and Society. Foottit, R.G., Adler, P.H. (eds.), Wiley Blackwell, Oxford, UK, 107162.

Konstantinov, A.S., Baselga, A., Grebennikov, A.A., Prena, J., Lingafelter, S.W. (2011). Revision of the Palearctic Chaetocnema Species (Coleoptera: Chrysomelidae: Galerucinae: Alticini). Pensoft Publishers, Bulgaria.

Lundin, O. (2020). Economic injury levels for flea beetles (Phyllotreta spp.; Coleoptera: Chrysomelidae) in spring oilseed rape (Brassica napus; Brassicales: Brassicaceae). Journal of Economic Entomology, 113(2): 808813.

Nielsen, J.K. (1988). Crucifer-feeding Chrysomelidae: Mechanisms of host plant finding and acceptance. In: Biology of Chrysomelidae. Jolivet, P., Petitpierre, E., Hsiao, T.H. (eds.), Kluwer Academic Publishers, Dordrecht, The Netherlands, 25-40.

Oerke, E.C., Dehne, H.W., Schonbeck, F., Weber, A. (1994). Crop production and crop protection: Estimated losses in major food and cash crops. Amsterdam, The Netherlands.

Olfert, O., Weiss, R.M., Woods, S., Philip, H., Dosdall, L. (2004). Potential distribution and relative abundance of an invasive cereal crop pest, Oulema melanopus (Coleoptera: Chrysomelidae), in Canada. The Canadian Entomologist, 136(2): 277-287. 
Özdikmen, H., Özbek, H., Kaya, G., Topcu, N. (2012). A contribution for knowledge of Turkish leaf beetles (Chrysomeloidea: Chrysomelidae). Munis Entomology and Zoology, 7(2): 1065-1072.

Özdikmen, H. (2014). Chorotype identification for Turkish Chrysomeloidea (Coleoptera) Part VIII - Chrysomelidae: Alticinae. Munis Entomology and Zoology, 9(1): 325-375.

Özdikmen, H., Özbek, H. (2014). Chorotype identification for Turkish Chrysomeloidea (Coleoptera) Part IV Chrysomelidae: Donaciinae and Criocerinae. Munis Entomology and Zoology, 9(1): 161-169.

Özdikmen, H., Mercan, N., Cihan, N., Kaya, G., Topcu, N., Kavak, M. (2014). The importance of superfamily Chrysomeloidea for Turkish biodiversity (Coleoptera). Munis Entomology and Zoology, 9: 17-45.
Özdikmen, H., Coral Şahin, D., Bal, N. (2017). New food plants and new records of two species of Epitrix Foudras in Turkey (Chrysomelidae: Galerucinae: Alticini). Munis Entomology and Zoology, 12(1): 309-312.

Rashidov, M.I., Khasanov A. (2003). Pests of sugar beet in Uzbekistan. Zashchita i Karantin Rasteniĭ, 3, 29.

Santiago-Blay, J.A. (2004). Leaf-mining chrysomelids. In: New Developments on the Biology of Chrysomelidae. Jolivet, P., Santiago-Blay, J. A., Schmitt, M. (eds.), SPB Academic Publishing, The Hague, The Netherlands, 183.

Warchałowski, A. (2010). The Palearctic Chrysomelidae: Identification Keys, Vol: 2. Natura Optima Dux Foundation, Warszawa.

Yaman, M., Radek, R., Toguebaye, B. (2008). A new microsporidian of the genus Nosema, parasite of Chaetocnema tibialis (Coleoptera: Chrysomelidae) from Turkey. Acta Protozoologica, 47: 279-285. 